\title{
Ewa Nowak
}

Uniwersytet im. Adama Mickiewicza w Poznaniu

\section{Funkcjonowanie nazwisk pochodzenia niemieckiego w siedemnasto- i osiemnastowiecznych rejestrach poznańskich podatników czopowego. Świadectwa polonizacji}

W literaturze onomastycznej nazwisko obce definiowane jest jako nazwisko nieposiadające motywacji na gruncie języka polskiego. Kazimierz Rymut we wstępie do słownika historyczno-etymologicznego Nazwiska Polaków pisze:

Rodzimymi będą te nazwiska, które pochodzą od wyrazów pospolitych używanych w polskim języku, od imion używanych przez Polaków, od nazw geograficznych określających obiekty znajdujące się na terenie Polski. Obce są zatem takie nazwiska, które takich podstaw nie mają ${ }^{1}$.

Zastrzega jednak, że nazwiska powstałe od wyrazów genetycznie obcych, zapożyczonych do polszczyzny w historii języka, uważa się za nazwiska rodzime. W innym miejscu wstępu wyjaśnia dokładnie:

Nazwami obcymi są takie, które zostały przetransponowane do naszego języka już jako gotowe nazwy osobowe i w polszczyźnie nie nastąpiła zmiana ich funkcji nazewniczych. Do języka polskiego przenikały obce nazwy w różnych okresach, w różnych stadiach rozwoju systemu nazewniczego. Nazwy obce istniały już w systemie jednoimiennym, w okresie tworzenia się systemu dwuimiennego i przybywały w okresie ustabilizowanego już nazwiska ${ }^{2}$.

W pracy tej poświęcam uwagę nazwiskom genetycznie niemieckim oraz tzw. hybrydom, tj. nazwiskom posiadającym motywację antroponimiczną

${ }^{1}$ K. Rymut, Nazwiska pochodzenia obcego, w: idem, Nazwiska Polaków. Stownik historyczno-etymologiczny, t. 1, Wrocław 1999, s. 65-75.

${ }^{2}$ Ibidem. 
w języku polskim, utworzonym z elementów polskich i niemieckich. Artykuł przedstawia funkcjonowanie nazwisk pochodzenia niemieckiego, noszonych przez mieszczan poznańskich siedemnastego i osiemnastego wieku. Opiera się na ekscerpcji źródeł archiwalnych, jakimi są spisy podatku czopowego, płaconego przez obywateli Poznania we wskazanym czasie ${ }^{3}$. Biorąc pod uwagę częstość wystąpienia nazw genetycznie niemieckich w przebadanych rejestrach, należy stwierdzić, że udział tych nazw kształtuje się nierównomiernie w kolejnych spisach rocznych. Z zachowanych wykazów podatkowych wynika, że w latach 1634-1654 poświadczono znaczniej mniej nazwisk niemieckich w stosunku do obfitujących w nie roczników: 1658, 1659, 1660, a w szczególności roczników: $1704,1714,1715,1721,1722$. Spisy z lat 1673-1689 oraz 1730-1762 wykazują stosunkowo niewielką częstość wystąpienia nazwisk niemieckich (porównywalną do lat 1634-1654), natomiast w rocznikach 1784, 1785, 1786, 1787 i 1788 użycie nazwisk niemieckich znów widocznie wzrasta. Wyjaśnienia tego zjawiska szukać należy w dziejach Poznania ${ }^{4}$, przede wszystkim w udziale obcych władz w mieście podczas najazdu szwedzkiego w latach sześćdziesiątych XVII wieku oraz podczas wojny północnej w pierwszym dwudziestoleciu wieku XVIII. Druga połowa XVIII wieku również przebiegała pod znakiem wojen i obecności różnych sił zbrojnych. Niewątpliwie w tym też czasie w Poznaniu znacznie zwiększa się liczba zagranicznych przybyszów wnoszących do społeczności miejskiej nowe nazwiska.

Punktem wyjścia w opisie nazwisk jest ich motywacja, a metodą badawczą analiza motywacyjna, dająca określone typy nazwisk, wśród których znalazły się nazwiska motywowane przez niemieckie nazwy własne oraz niemieckie apelatywy. W zbiorze wszystkich genetycznie obcych nazwisk poznaniaków, stanowiących blisko $20 \%$ materiału onomastycznego poświadczonego $\mathrm{w}$ archiwaliach, w ogromnej większości zaznaczyły się właśnie nazwiska niemieckie $^{5}$ lub nazwiska pochodzenia niemieckiego ${ }^{6}$. Najczęściej ulegały one

${ }^{3}$ Dokumenty pochodzą z zespołu Akta Miasta Poznania Archiwum Państwowego w Poznaniu, wykorzystane zostały w projekcie badawczym Nazwiska mieszkańców Poznania na tle antroponomastykonu innych miast wielkopolskich i ewolucji polskiego systemu antroponimicznego realizowanym na Uniwersytecie im. Adama Mickiewicza w Poznaniu pod kierunkiem prof. dr hab. Ireny Sarnowskiej-Giefing. Zob. Stownik nazwisk mieszkańców Poznania XVI-XVIII wieku, red. I. Sarnowska-Giefing, t. 1, A-F, Poznań 2011, tu w szczególności rozdział V: Charakterystyka wykorzystanych źródet, s. 53-57.

${ }^{4}$ Zob. Dzieje Poznania, red. J. Topolski, t. 1, Warszawa-Poznań 1988.

${ }^{5}$ Nazwiska niemieckie poświadczone w słownikach: Familiennamen. Herkunft und Bedeutung von 20000 Nachnamen, oprac. R., V. Kohlheim, Mannheim-Leipzig-Wien-Zürich 2005; M. Gottschald, Deutsche Namenkunde, Berlin-New York 1982.

${ }^{6}$ Etymologię wszystkich cytowanych w pracy nazwisk pochodzenia niemieckiego ustaliłam na podstawie źródeł: Słownik etymologiczno-motywacyjny staropolskich nazw osobowych, 
polonizacji na płaszczyźnie fonetycznej i morfologicznej. Mniejszą ich część przejmowano do języka polskiego w oryginalnej postaci.

Silny wpływ języka niemieckiego wynikał z częstych migracji ludności ${ }^{7}$, kontaktów handlowych i urzędniczych. Jak wspomniałam, udział nazwisk niemieckich w poznańskiej antroponimii niewątpliwie zwiększała wojenna zawierucha XVII i XVIII wieku, która przyciągnęła do miasta siły saskie, brandenburskie i pruskie. Wiele nazwisk niemieckich zostało przeniesionych jako gotowe jednostki językowe do systemu polskiego, nie towarzyszyła im zmiana funkcji, pozostawały nazwami osobowymi. Specyfika ich polega na tym, że nie posiadają żadnych podstaw motywujących w języku polskim. Zostały zapisane w spisach podatkowych w niezmienionej, niespolszczonej postaci, a większość z nich znalazła też poświadczenie w niemieckich słownikach ${ }^{8}$. Są to nazwiska: Adler, Baur, Böhm, Braun, Deibel, Eckler, Elbing, Gebler, Giering, Hasler, Heinrich, Helbing, Kaul, Keller, Klaus, Klein, Korn, Kosche, Meller, Merker, Miller, Ner, Pfeiffer, Raffel, Rang, Sauer, Saupe, Schmidt, Tepper, Unrug, Walter, Werner, Wiegandt, Winkler, z których niemal wszystkie funkcjonują współcześnie jako nazwiska Polaków9 ${ }^{9}$.

Odmianki graficzne nazwisk genetycznie obcych niewątpliwie świadczą o próbie ich polonizacji, dowodzą jednocześnie braku stabilizacji tych form w polskim systemie. Za przykłady niech posłużą formy nazwisk zachowujące żywotność do dnia dzisiejszego, poświadczone w Słowniku nazwisk współcześnie $w$ Polsce używanych ${ }^{10}$, takie jak: Gebler z odmianami graficznymi Giebler, Gibler; Keller z odmianą graficzną Kieler; Wentland z odmianą graficzną Wentlant. Elżbieta Rudnicka-Fira w pracy Antroponimia Krakowa od XVI do XVIII wieku. Proces ksztattowania się nazwiska pisze:

Zazwyczaj przejmujemy obce nazwiska wraz z ich nosicielami. Cudzoziemcy, osiedlając się w Polsce, stopniowo asymilowali się z ludnością rodzimą i byli włączani w obręb kultury polskiej. Z czasem, w następnych pokoleniach mogli stawać się Polakami, przyjmując narodowość i obywatelstwo polskie. Ich nazwiska

cz. 5: Nazwy osobowe pochodzenia niemieckiego, oprac. Z. Klimek, Kraków 1997; K. Rymut, Nazwiska Polaków. Stownik historyczno-etymologiczny, t. 1, 2, Kraków 1999-2001; Familiennamen...

${ }^{7}$ Zob. K. Banderowicz, Hybrydowe spoleczeństwo. O procesach imigracyjnych na podstawie onimów historycznych mieszkańców Poznania, w: Mnohotvárnost a specifičnost onomastyki (IV. česka onomastická konference), 15-17. záři 2009, Ostrava, sbornik príspěvků, Ostrava-Praha 2010, s. 29-37.

${ }^{8}$ Familiennamen...; M. Gottschald, Deutsche Namenkunde...

9 Zob. Stownik nazwisk współcześnie w Polsce używanych, red. K. Rymut, t. 1-10, Kraków 1992-1994.

${ }^{10}$ Ibidem. 
pozostawały jednak obce językowo. Z biegiem czasu nazwiska te mogą ulegać procesom polonizacyjnym, głównie zmianom fonetycznym, graficznym, także fleksyjnym (rzadziej słowotwórczym) ${ }^{11}$.

Wiele nazwisk o obcych podstawach zakorzeniło się w polszczyźnie, osiągnęło stabilizację i rodzinność, czego wyrazem mogą być różne warianty graficzne pierwotnie jednego antroponimu, funkcjonujące dziś jako odrębne nazwiska. Ilustrują to przykłady ze Stownika nazwisk wspótcześnie w Polsce używanych, identyfikujące częstokroć również mieszczan poznańskich w XVII i XVIII wieku - np. nazwiska Schmidt, Schmitt, Szmid, Schmid, Schmidl czy nazwiska Szulc, Schultz, Schulc, Schulz.

Nazwiska niemieckie ulegały w dużym stopniu polonizacji. Formy spolonizowane stanowią większość omawianego zasobu antroponimicznego. $\mathrm{Na}$ płaszczyźnie fonetycznej zjawisko to przejawia się w uproszczeniach zapisu zgodnie z polską fonetyką i z polskimi regułami ortograficznymi: Bajer od nazwy etnonimicznej Bayer, Beyer 'Bawarczyk'; Braszwik od niemieckiej nazwy miejscowej Braunschweig; Cygier od niemieckiej nazwy osobowej Ziger lub Zieger; Deryng od niemieckiego nazwiska Dering, podobnie: Dytmer od Dittmer, Dytrich od Dietrich, Fibich od Fiebich, Giec lub Giecz od Götz, Ginter od Gunter lub Ginther, Majer od Meier, Mejsner od Meisner, Nejman od Naumann, Risner od Rösner, Rozman od Rossmann, Rychter od Richter, Szefel od Schäffel lub Scheffel, Szubert od Schubert, Szulc od Schultz, Wejnert od Weinert. Powszechną cechę procesu adaptacji językowej stanowi zastępowanie niemieckich samogłosek z przegłosem przez polskie samogłoski najbliższe im brzmieniowo. Typowym procesem adaptacji fonetycznej jest również oddawanie połączeń samogłoskowych ie przez samogłoski $i$ oraz y (np. Rydrych od Riedrich), a także nierzadka polonizacja wygłosu (np. Wilant od Wieland). Bardzo częstą cechą są różne substytucje fonologiczne, np. zastępowanie niemieckiej zbitki -sch- przez jej polski odpowiednik brzmieniowy -sz-, co ilustruje forma Hersz od niemieckiego nazwiska Hersch. Antroponim Polcyn stanowi adaptację, na gruncie fonetycznym i zarazem morfologicznym, nazwiska niemieckiego z podstawą Polz (np. Polzin) - podstawą będącą zarówno nazwą osobową, jak i miejscową w języku niemieckim. Zdarzają się także uproszczenia graficzno-fonetyczne i graficzne typu Edeman od niemieckiego nazwiska Edelmann oraz szereg nazwisk: Akiermann od Akkermann, Herman od Hermann, Hoffman od Hoffmann, Kinderman od Kindermann, Polman od Pollmann lub Pohlmann, Tylman od Tillmann, w zapisie których wyraźnie

${ }^{11}$ E. Rudnicka-Fira, Antroponimia Krakowa od XVI do XVIII wieku. Proces ksztaltowania się nazwiska, Katowice 2004, s. 168. 
unikano podwojonych spółgłosek czy niemego $h$. Likwidowano też głoskę $h$ w zbitkach th, zastępując ją samym $t$, np. Ginter zamiast Ginther. Jak pisze Kazimierz Rymut:

z zasady bez zmian fonetycznych przyjmowane były te nazwy, które zawierały głoski wymawiane w języku niemieckim tak samo jak i w języku polskim. [...] Jeśli w nazwie niemieckiej występowała głoska różniąca się wymową od zbliżonej głoski polskiej lub gdy w języku polskim nie występowała taka głoska czy grupa głosek, to wtedy przy przejmowaniu nazwy niemieckiej następowało podstawienie głoski polskiej dźwiękowo najbliższej ${ }^{12}$.

Obce nazwy osobowe włączano z łatwością do polskich paradygmatów fleksyjnych, np. Rozmanowi, Szfertmanowi, Schuberta, Szlichyna, Szulertowej, Szwejnertowej. Wspomnieć należy o specyficznym sposobie nazywania kobiet obejmowanych nazwiskiem męża, do którego dodawano polski formant marytonimiczny -owa. W ten sposób powstały identyfikacje kobiet typu Deryngowa, Ecclerowa, Helbingowa, Patonowa, Rechfeldowa. Obce genetycznie nazwisko córki z polskim przyrostkiem prezentuje przykład Rychterówna. Kobiety nazywane zwyczajowo niemieckim antroponimem męża były identyfikowane przez wykładniki żeńskości właściwe tylko polskiej tradycji antroponimicznej, co znów dowodzi przyswojenia wielu form obcych, od których z łatwością urabiano marytonimika, a zarazem nazwiska hybrydalne, takie jak Behrowa, Risnerowa, Wulficzka.

Do niemieckich podstaw dodawano także polskie przyrostki nazwiskotwórcze. Formacje tego typu w literaturze przedmiotu nazywane bywają hybrydami. W odczuciu językowym współczesnych Polaków prawdopodobnie nie są już strukturami genetycznie obcymi z uwagi na polskie przyrostki antroponimiczne, np. Fleminkowski - nazwisko urobione od niemieckiego nazwiska Fleming za pomocą polskiego sufiksu -owski; Marchlewski-nazwisko od niemieckiej nazwy osobowej Markel z polskim sufiksem -ski; Wentzki - nazwisko mające w podstawie prawdopodobnie niemieckie nazwisko Wenz z polskim sufiksem -ski, bądź będące postacią niemieckiego nazwiska Wenske. Mardefelt stanowi twór, którego budowa pokazuje zjawisko odwrotne niż w powyższych przykładach, do podstawy Mard- tworzącej polskie nazwiska typu Mardej lub Mardel dodano niemiecki człon Feld od apelatywu Feld 'pole'. Orlandtz kolei - jest antroponimem pochodzącym od polskiej nazwy heraldycznej Orla i posiadającym niemiecką końcówkę -ndt. Nazwiska z polskimi sufiksami nazwiskotwórczymi, które dają kolejne przykłady tworów hybrydalnych

${ }^{12}$ K. Rymut, Nazwiska pochodzenia obcego..., s. 67. 
to m.in.: Gierłowski od niemieckiej nazwy osobowej Gerlach pochodzącej od imienia Gerwald; Hamplewicz od niemieckiej nazwy osobowej Hampel pochodzącej od apelatywu Hampel 'błazen'; Hanowicz od niemieckiego imienia Han będącego spieszczoną formą imion Johann, Joahannes; Kalkowski od niemieckiej nazwy osobowej Kalk wywodzonej od średnio-wysoko-niemieckiego kalc 'wapno'; Kinosowicz od niemieckiej nazwy osobowej Kinast od apelatywu Kienast 'konar sosny', Konkowicz od niemieckiej nazwy osobowej Kohnke; Szpanka od niemieckiej nazwy osobowej Span od średnio-wysoko-niemieckiego spän 'drzazga', przenośnie 'mały człowiek'; Sztorkowski od niemieckiej nazwy osobowej Stork od średnio-wysoko-niemieckiego storc 'bocian', Trampski od niemieckiej nazwy osobowej Trampe pochodzącej od nazwy miejscowej o tej samej postaci bądź od niemieckiej nazwy osobowej Trams, ta od nazwy osobowej Tram; Wolkiewicz i Wolkowicz od niemieckiej nazwy osobowej Wolk; Wulfowicz od nazwy osobowej Wolf od niemieckiego apelatywu Wolf 'wilk', Zandrowicz od niemieckiej nazwy osobowej Sand ${ }^{13}$.

Małgorzata Jaracz, autorka monografii poświęconej nazwiskom mieszkańców Kalisza doby średniopolskiej, zauważa, że wśród kaliskich nazwisk pochodzenia obcego zasadniczy udział mają formy niemieckie i łacińskie ${ }^{14}$. Podtyp niemiecki świadczy o procesach kształtowania się miast polskich na prawie magdeburskim (później prawie średzkim). Nazwiska niemieckie, podobnie jak rodzime, badaczka grupuje według trzech typów strukturalnych: prymarne (niederywowane), sekundarne i złożenia. Nazwiska prymarne powstają przede wszystkim od wyrazów pospolitych różnego typu. Grupę tę prezentowałyby następujące przykłady nazwisk poznaniaków: Lang od apelatywu określającego właściwość fizyczną lang 'długi', podobnie spolszczone Krauza od apelatywu kraus 'kędzierzawy', Adler od apelatywu Adler 'orzeł', Wulf, z wielkopolską fonetyczną cechą gwarową - $u$ - zamiast -o-, od apelatywu Wolf 'wilk'. Nazwy zawodów i funkcji społecznych dały takie nazwiska, jak: Hoffman (od apelatywu Hoffmann 'dworzanin'), Kieler (od apelatywu Keller 'piwniczny, zarządca piwnic'), Majer (od apelatywu Meier 'dzierżawca'), Miller (od apelatywu Müller 'młynarz'), Rychter (od apelatywu Richter 'sędzia'), Rozman (od apelatywu Rosemann 'handlarz rodzynkami'), Szubert (od apelatywu Schubert 'szewc'), Szulc (od apelatywu Schultz 'sołtys'). Do nazwisk prymarnych należy zaliczyć także niemieckie nazwiska równe imionom, jak nazwisko Dytrich od imienia Dietrich, oraz nazwiska równe nazwom etnicznym, np. Deryng od nazwy Dering 'mieszkaniec Turyngii' ${ }^{15}$. Nazwiska

${ }^{13}$ Zob. źródła w przypisie 5 .

${ }^{14}$ Zob. M. Jaracz, Nazwiska mieszkańców Kalisza od XVI do XVIII wieku, Bydgoszcz 2001.

${ }^{15}$ Zob. źródła w przypisie 5. 
sekundarne zaś tworzone są przez niemieckie sufiksy o wyspecjalizowanych funkcjach: -er i rozszerzone -ner, -ert, wskazujące mieszkańca danej miejscowości lub państwa albo mężczyznę wykonującego zawód nazywany przez czasownik; -e tworzący głównie wyrazy abstrakcyjne oraz -chen i -in jako wykładniki zdrobnień, spieszczeń, a także żeńskości w przypadku -in ${ }^{16}$. Według tego formalnego kryterium dominujące wśród niemieckich nazwisk poznaniaków wydają się nazwiska z sufiksem -er. Do grupy złożeń natomiast dają się zaszeregować nazwiska z członem -mann (apelatyw Mann 'człowiek') typu: Herman, Polman, Tylman.

Pozostając w zgodzie z tezą Rudnickiej-Firy, należy stwierdzić, że „,trudno jest zatem bez szerszego kontekstu lub innych dodatkowych informacji wnioskować o pochodzeniu nazwisk obcych, nie zawsze są one jednoznaczne"17. Wielomotywacyjność nazwisk, niemożność ustalenia ich jednoznacznej etymologii, jest zjawiskiem bardzo częstym w badanym materiale. Nierzadko trzeba było zmierzyć się z nazwiskami o podwójnej czy potrójnej motywacji, z których jedna, czasem dwie odnoszą się do nazwy niemieckiej. Przykłady stanowią nazwiska: Bryza (obok motywacji przez apelatyw bryndza, bryndża 'ser owczy' lub łużycki apelatyw breza 'brzoza' może być ono motywowane zniemczoną nazwą osobową Briese), Dera (z podstawą der- np. w apelatywie dera 'grube okrycie' bądź niemiecka nazwa osobowa Dähre, Därr), Lamparski (motywowane niemieckim imieniem Lampert bądź wyrazem pospolitym lampart), Oldenburski (od niemieckiej nazwy miejscowej Oldenburg bądź złożenie z niemieckiej podstawy alt, dolnoniemieckiej old 'stary' i polskiego nazwiska Burski od nazwy miejscowej Burcz), Paton (motywowane przez podstawę pat- np. pat 'termin szachowy', patać 'machać' lub niemiecką nazwę osobową Pate), Raba (od podstawy rab-np. dawne rab 'niewolnik, poddany', rabi 'honorowy tytuł nauczyciela żydowskiego', możliwe też gwarowe raby 'ospowaty' lub niemieckiego apelatywu Rabe 'kruk'), Reglewicz (w podstawie apelatyw rygiel, dawniej też regiel 'zasuwa, zamknięcie' lub niemiecka nazwa osobowa Rigel, Riegel), Rossowski (motywowane apelatywem rosa lub niemiecką nazwą osobową Roß), Seferowicz (nazwisko, które może pochodzić od apelatywu szafarz, ale także od niemieckiej nazwy osobowej Schaffer lub nazwiska Sefer od imienia złożonego Sigifrith), Sendys (obok polskiej motywacji przez imiona złożone Sędzimir, Sędzisław lub apelatywa sąd, sądzić, sędzia możliwa motywacja przez niemiecką podstawę Send-), Szafarski (od apelatywu szafarz lub niemieckiej nazwy osobowej Schaffer), Szaje (od podstawy Szaj- np. w imieniu Isaj używanym w dawnej Polsce wschodniej, w ape-

\footnotetext{
16 M. Jaracz, op.cit., s. 485.

17 E. Rudnicka-Fira, op.cit., s. 173.
} 
latywie szaja 'tkanina jedwabna' lub niemieckiej nazwy osobowej na Schei-), Szlichtyn (w podstawie apelatywa szlichta 'klej tkacki', szlicht 'miał rudy' lub niemiecka nazwa osobowa Schlichte, ale możliwa jest także motywacja przez niemiecki apelatyw schlichten 'gładzić, polerować, ostrzyć'), Zajdzik (w podstawie apelatyw zajść, zajdę lub staropolski apelatyw zajda 'kosa', też 'płachta do noszenia siana', możliwa jest jednak motywacja przez niemiecką nazwę osobową Seide $)^{18}$. Przyjęcie motywacji przez nazwy niemieckie sprawia, że liczne z powyższych form stanowią na płaszczyźnie morfologicznej kolejne przykłady struktur hybrydalnych.

W badanym materiale nazwiska pochodzenia niemieckiego, poddawane różnego rodzaju adaptacjom na płaszczyźnie języka polskiego, przeważały liczebnie nazwiska czysto niemieckie. Większość nazwisk pochodzenia niemieckiego pozostała żywotna i znalazła poświadczenie w zasobie współczesnych antroponimów polskich, czego dowodzi ich występowanie w Stowniku nazwisk wspótcześnie w Polsce używanych. Często jednoznaczne ustalenie etymologii niemieckiej niektórych form okazywało się niemożliwe, co zmuszało do postawienia tezy o wielomotywacyjności poznańskich antroponimów, które obok motywacji przez polską nazwę własną lub wyraz pospolity, odnosiły się także do niemieckich nazw własnych i apelatywów. Warto jednak przytoczyć słowa Rudnickiej-Firy mówiące, że „obcość nazwy nie zawsze musi być wyznacznikiem obcości nosiciela, często nie ma wpływu na poczucie przynależności narodowej człowieka, tym samym na jego losy, życie"19.

\section{Ewa Nowak}

\section{On the functioning and development of surnames of German origin in seventeenth and eighteenth century registers of Poznań-based taxpayers registered for the purpose of the tax on production and sale of alcoholic beverages. The evidence of Polonization}

The proposed paper presents the functioning of German-origin names with their root and etymology of German origin borne by Poznan burghers in the seventeenth and the eighteenth centuries. The source material for the study was provided by archival registers of the taxpayer of the tax on production and sale of alcoholic beverages. The work has attempted to determine the motivation behind the names and to track down their development, while the applied research method involves the motivational analysis that results in a pool of particular types of surnames that includes surnames motivated by German proper names and German appellatives. The set of all foreign

\footnotetext{
18 Zob. źródła w przypisie 5.

19 E. Rudnicka-Fira, op.cit., s. 174.
} 
surnames of the population of Poznań, amounting to nearly $20 \%$ of all onomastic material attested in the available archival documents, includes far more German surnames or surnames of German origin than any other surnames. In time, the given names of German people were Polonized both in the phonetic and the morphological plane. A small part of them was incorporated into the Polish language in their original form. In the material under scrutiny the Polonized forms were in preponderance as compared to purely German names. Language adaptation was also responsible for the formation of surnames of women - hybrid feminine forms from German names with Polish feminine suffixes appended onto foreign names. On numerous occasions it was impossible to unequivocally establish the German etymology of some of the surnames, which forced a conclusion leading to a proposition of a multi-motivational character of Poznań anthroponyms that, beside the motivation by a Polish anthroponym or appellative, also referred to German anthroponyms and appellatives. The bulk of surnames of German origin have remained vital and have been testified in the resources of presentday Polish anthroponyms.

KEY WORDS: onomastics, anthroponymy, surnames, linguistic adaptability.

mgr Ewa Nowak, Zakład Historii Języka Polskiego, Instytut Filologii Polskiej Uniwersytetu im. Adama Mickiewicza w Poznaniu; zainteresowania badawcze: historia języka polskiego, onomastyka, antroponimia. 